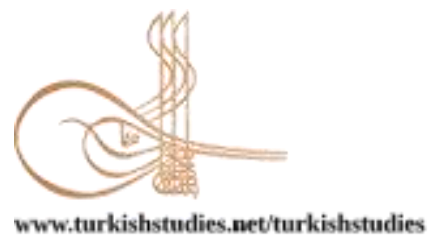

Turkish Studies

\title{
Masallarımızdaki İletileri Vermede Kadın Kahramanların Rolü
}

\author{
The Role of Women Heroes to Give Messages in our Tales
}

\author{
Kevser Taş̧̧ı* - Erhan Akın**
}

\begin{abstract}
The tale, which is formed with the tradition of oral expression and has a spreading area, is one of the oldest favorite text types with its fiction processed with extraordinary features. Tales developed and changed in interaction with the society and traveled geographies by going beyond the boundaries of the space from which they emerged. Although extraordinary persons and events are encountered, the emotions discussed reflect the reality of human nature. The prominence of women as storytellers has caused many feelings and information about women to enter the narratives. The roles of women in the fairy tale world are similar to the roles we encounter in real life. In our tales, it is possible to come across profiles of women who have positive character traits accepted by the society and women who are rejected by the society. With these narratives, the listeners become aware of women's activities in the world of fairy tales and create a perspective on women with their real life experiences. Tales reflect the traditions, customs and beliefs of the societies they belong to, while also presenting the social, cultural and economic data of these societies to their readers. The duties assigned to women and men by the society are explained with the concept of gender. The gender perspective of society imposes certain duties and responsibilities on sexual identities. Despite all the extraordinary things told in our tales, human emotional states are closely related to the identities of men and women in daily life. The inadequacy of the studies on the female characters in our fairy tales drew attention in the readings. This shortcoming in the field has been the starting point of the study. In our study, a window was opened to our women from the world of fairy tales, and the role of female karamans in giving messages in our fairy tales in the context of gender was examined.
\end{abstract}

Structured Abstract: Tales that transcend the boundaries of the society in which they were born from past to present by word of mouth, undoubtedly included the cultural elements of the societies they came out of and visited, thus gaining a universal character. Although the expressions are extraordinary, the emotional states they describe are based on real life practices. Always winning the good and punishing the bad are situations that human nature seeks. In listening environments where the receiver is a child, the messages given through tales for the listeners whose personality development continues, convey the behavioral characteristics that are accepted and not accepted by the society, thus preparing the child for real life environments.

\footnotetext{
* YL Öğrencisi, Siirt Üniversitesi, Sosyal Bilimler Enstitüsü, Türkçe Eğitimi Bölümü Grad. Student, Siirt University, Social Sciences Institute, Turkish Education Department ORCID 0000-0002-7257-9934

tsc.kvser@gmail.com

** Doç. Dr., Siirt Üniversitesi, Eğitim Fakültesi, Türkçe ve Sosyal Bilimler Eğitimi Bölümü Assoc. Prof. Siirt University, Faculty of Education, Department of Turkish and Social SciencesEducation ORCID 0000-0003-2372-9331 erhanakin49@hotmail.com

Cite as/ Atıf: Taşçı, K., \& Akın, E. (2021). Masallarımızdaki iletileri vermede kadın kahramanların Rolü. Turkish Studies, 16(1), 377-388. https://dx.doi.org/10.7827/TurkishStudies.47634

Received/Geliş: 16 November/Kasım 2020

Checked by plagiarism software

Accepted/Kabul: 20 Şubat/February 2021 
The connection of tales with daily life, especially the transfer of many cultural elements to other generations in their memory, has created a need for studies on texts. Relationships between men and women, the duties and responsibilities that societies attribute to the sexes have also taken place in the world of fairy tales.

When we look at our environment, such as accepting mothers, rejecting and frightening stepmothers, women trying to protect their chastity and dignity, mothers, fathers and children trying to overcome difficult situations, we actually see that the fairy tales are renewed every moment in real life. (Akar,2006:274)

Fairy tales lead people to behave virtuously to goodness and beauty through their messages. Heroes play various roles in conveying messages to the reader. Since the narrators are mostly women, the female hero cadre in the fairy tales has a large place. The inadequacy of studies on the female characters in our fairy tales drew attention in the readings. This shortcoming in the field has been the starting point of the study. The aim of the study is to create a perspective about women in the context of gender in general and to reveal the role of women in giving story messages in particular.

Methot. The tales included in the sample group of the study are those in the works of Naki Tezel, Tahir Alangu, Pertev Naili Boratav and Aydın Parmaksiz. While choosing the tales to be the subject of the study, the hero staff was taken into consideration and especially the tales in which the female identity stands out were selected. While analyzing the tales, one of the qualitative research methods, document analysis method was used. The tales compiled by the researchers from Naki Tezel, Tahir Alangu, Pertev Naili Boratav were read in two different processes. The first reading was done without purpose. The second reading was done in the center of the role of the heroines in the fairy tales in delivering the messages. The obtained data were processed into forms by the researchers. The data were analyzed in depth with content analysis and the role of female heroes in giving messages was investigated. The processed data were collectively analyzed by the researchers in the findings section.

Results. According to the results of the examination, the messages given by the heroes in the fairy tales were determined as follows: They are the heroes who make the nest in the fairy tales and try to maintain their continuity, sometimes holding and protecting their family, who endure even a second woman, above everything else. The persuasive power of stepmothers in our fairy tales is quite high. They skillfully conceal the tortures they have made, the lies they tell, the treacherous plans they have set up, and persuade the main heroes to do whatever they want until they become victims. Women posing danger are women who can take an active role in their lives trying to direct their own destiny. They do not act on the will of a man. The man overcomes the types of women whose duty is to do evil by fighting or using his cunning. The giant mother surrenders when her breast is sucked. Surrender is also shown in front of the first kiss where virginity is at stake. The male hero sucking the giant breast of his mother is now his son. However, at the end of the tale, the hero, who has no reason left, will prefer to kill the evil female, even though she has surrendered. (Sezer, 2019:47)

It is seen as an element of danger coming from outside the house in the relationship of women with women, so power wars begin. "Women entering the household later do not always accept their fate and remain in the" other "position for the rest of their lives. After a while, they also make an effort to become the "main woman" in the household "(Ölçer, 2003: 41). For stepmothers, the struggle for existence is among the frequently discussed topics in our fairy tales. What is expected from women in the eyes of society is to depend on men. Man's strength is measured by his dominance over women. When our fairy tales are examined, it is seen that our young girls, who deserve a happy ending, display a passive attitude. The fairy tale world prepares different endings for individuals who commit the crime of infidelity according to their gender. In the fairy tale "Benli Bahri", the woman who cheated on her husband was punished.

Keywords: Folk science, fairy tale, gender, woman, role, message

Öz: Sözlü anlatım geleneği ile oluşan ve yayılma alanı bulan masal, olağanüstülükler ile işlenmiş kurgusuyla en eski en sevilen metin türlerindendir. Masallar toplumla etkileşim halinde gelişmiş, değişmiş ve içinden çıktığı mekânın sınırlarını aşarak coğrafyalar gezmiştir. Her ne kadar olağanüstü kişiler ve olaylar ile karşılaşılsa da ele alınan duygular insan doğasının gerçeğini yansıtmaktadır. Kadınların masal anlatıcıları olarak ön planda olması anlatılara kadına dair pek çok hissin, bilginin girmesine vesile olmuştur. Masal dünyasında yer alan kadın rolleri, gerçek hayatta karşılaştığımız roller ile benzerlik göstermektedir. Masallarımızda toplum tarafından kabul gören olumlu karakter özelliklerine sahip kadınlar ile toplum 
nezdinde reddedilmiş kadın profillerine rastlamak mümkündür. Bu anlatılar ile dinleyiciler, masal dünyasındaki kadın etkinliklerinin farkına varmakta gerçek hayat tecrübeleri ile de kadına dair bir bakış açısı oluşturmaktadır. Masallar ait oldukları toplumların gelenek, görenek ve inançlarını yansıtırken aynı zamanda bu toplumların sosyal, kültürel, ekonomik verilerini de okuyucularına sunmaktadır. Toplum tarafından kadın ve erkeklere verilen görevler toplumsal cinsiyet kavramı ile açıklanmaktadır. Toplumun cinsiyetlere bakış açısı, cinsel kimliklere belirli görev ve sorumluluklar yüklemektedir. Masallarımızda anlatılanlar tüm olağanüstülüklere rağmen insan duygu durumlarıyla gündelik hayattaki kadın ve erkek kimlikleri ile yakından ilişkilidir. Yapılan okumalarda masallarımızdaki kadın karakterler üzerinde yapılmış çalışmaların yetersizliği dikkat çekmiştir. Alandaki bu eksiklik çalışmanın çıkış konusu olmuştur. Çalışmamızda masal dünyasından kadınlarımıza pencere açılmış, toplumsal cinsiyet bağlamında masallarımızdaki iletileri vermede kadın karamanların rolü incelenmiştir.

Anahtar Kelimeler: Halk bilim, masal, toplumsal cinsiyet, kadın, rol, ileti.

\section{Giriş}

Geçmişten günümüze kulaktan kulağa yayılarak doğduğu toplumun sınırlarını aşan masallar, şüphesiz bu yolculuklarında içinden çıktığı ve ziyaret ettiği toplumların kültür ögelerini de içine almış, böylece evrensel nitelik kazanmıştır. Anlatımlar her ne kadar olağanüstülük taşısa da anlattıkları duygu durumları gerçek hayat pratiklerine dayanmaktadır. İyinin her zaman kazanıp kötünün cezalandırılması, insan doğasının aradığı, ihtiyaç duyduğu durumlardır. İyilik ve kötülük karşıtlığı masallarda kahraman kadrosu üzerinden paylaştırılır. Bir tarafta çeşitli hileler, yalanlar ile gündelik işlerini halleden kimseler, diğer tarafta doğruluktan ve dürüstlükten vazgeçmeyen kimseler ile birlikte kurguya dâhil edilir.

İnsanın gündelik hayatta tecrübe ettiği tüm duygular masallarda olağanüstülükler ile birleşir. Kullanılan motifler saklı pek çok anlamı ifade eder. Bu sebeptendir ki masallar günümüze kadar araştırmacılar için her zaman ilgi odağı olmuştur. Çeşitli kuramlar ile masallardaki saklı anlamlar bulunup insanı yine insan gerçeği ile karşılaştırmak istenmiştir.

Masalların gündelik hayatla olan bu bağları, özellikle kültürel pek çok unsuru belleğinde diğer kuşaklara taşıması, metinler üzerinde inceleme çalışmalarına ihtiyaç doğurmuştur. Kadın erkek ilişkileri, toplumların cinsiyetlere yükledikleri görev ve sorumluluklar, masal dünyasında da yer bulmuştur.

Toplumsal cinsiyet kavramı, doğuştan getirilen cinsiyet gruplarına toplum tarafindan kültürel hafızanın da etkisiyle verilen vazifeleri ifade etmektedir. Her toplumun kadın ve erkeğe bakışı farklı olduğundan, kurulan ilişkilerde bireylerden beklenen görevler de farklılıklar gösterebilmektedir. Masallar, kadın ve erkeğin toplumda nasıl konumlandırıldığı konusunda bilgi vermektedir. Evrim Ölçer (2003), "Türkiye Masallarında Toplumsal Cinsiyet ve Mekân İlişkisi”" isimli çalışmasında masallarımızdaki kadınlar ile ilgili şöyle bir tespitte bulunur:

Kadınların hane içindeki görevleri, ev dışından aile birlikteliğine yönelen tehlike karşısında erkeğin etkisiz kaldığı durumlarda ona yardım etmektir. Erkeğin evden uzaklaştığı durumlarda namusunu korumak, erkek kendisinden uzaklaştığında onu tekrar kazanmak, zorunlu hâller dışında dışarı çıkmamak, eve sonradan gelen kadını tehdit olarak görüp etkisiz hâle getirmek kadınlara verilen görevlerdir (Ölçer, 2003: 19). Masallarda etki alanı daha çok ev olan kadın, hanedeki huzuru ve erkeğin evde olmadığı ya da yeterli olmadığı durumlarda güvenliği sağlamakla görevlidir. Tüm bunları yaparken de en çok dikkat ettiği şey, namusunu koruma görevidir. Bu uğurda kadın, kendi varlığından dahi vazgeçebilmekte, ölümü tercih etmektedir. Özellikle doğu toplumlarının bekârete ve namusa verdiği önemin masallara yansıma şeklidir.

Masallarımıza baktığımızda kadına ekonomik sorumlulukların yüklendiğine pek rastlamayız. Ataerkil toplum düzeninde olduğu gibi avc1lık ve toplayıcılık erkeğin göreviyken bunları işlemede kadının el becerisinden yararlanılmaktadır. Bu da kültürümüzün cinsiyet rolleri 
üzerindeki görev paylaşımına örnek teşkil etmektedir. Üreticisinin ve tüketicisin insan olduğu masallar bu yönüyle toplumla etkileşim halinde gelişmiş, değişmiş ve içinden çıktığı mekânın sınırlarını aşarak coğrafyalar gezmiştir. Her ne kadar olağanüstü kişiler ve olaylar ile karşılaşılsa da ele alınan duygular, insan doğasının gerçeğini yansıtmaktadır. Kadınların masal anlatıcıları olarak ön planda olması, anlatılara kadına dair pek çok hissin, bilginin girmesine vesile olmuştur. $\mathrm{Bu}$ anlatılar ile dinleyiciler masal dünyasındaki kadın etkinliklerinin farkına varmakta, gerçek hayat tecrübeleri ile de kadına dair bir bakış açısı oluşturmaktadır.

Masalların kuşaklar arasında kültürel hafızayı taşıma özelliği bu türün araştırmacılar tarafından ilgi odağı haline gelmesini sağlamıştır. Arapça kökenli "mesel" kelimesi dilimize masal olarak geçmiş ve çeşitli kaynaklarda şu şekillerde tanımlanmıştır:

"Genellikle halkın yarattığı, ağızdan ağıza, kuşaktan kuşağa sürüp gelen, çoğunlukla insanların veya tanrıların başından geçen, olağandışı olayları anlatan hikâye" (TS, C.2, 1998: 1510).

Masal bütünüyle hayal ürünü olan, olağanüstü olaylara ve varlıklara yer veren, belirli olmayan bir zaman ve yerde meydana gelen, insanların veya diğer varlıkların başından geçen olağanüstü olayları anlatan, öğüt veren sözlü anlatı türüdür (Artun, 2012: 120).

Masallarda olağanüstülükler önemli yer kaplamaktadır. Anlatılara cinler, periler, cadılar, dev anaları dâhil edilir. Genellikle görevleri kötülük yapmak olan bu tiplerin en büyük silahı sihirdir. "Küplerine binip veya sırtlarına sihirli yeleklerini geçirip bir yıllık yolu bir anda giderler. Kendilerine torbalarla verilen ziynetler için her türlü kötülüğü yaparlar" (Tezel, 2019: 15).

Yaratıcısı belli olmayan masalların anlatımında oldukça yalın bir konuşma dili kullanılır. $\mathrm{Bu}$ sebepten dolayı diğer edebi türlerde gördüğümüz uzun tasvirlere, karakter çözümlemelerine masallarda pek rastlamayız.

Zamanın ve mekânın genellikle belli olmadığı masallar "Evvel zaman içinde", "Ülkenin birinde", "Zamanlardan bir zaman" gibi ifadeler ile başlar. Böylece anlatılanlar, zaman ve zemin unsurlarının çerçevesinden kurtarılır. Kahramanlar da yine çoğunlukla cin, peri, padişah, akıllı küçük oğlan gibi genel tiplemelerdir. Tüm bu belirsizlikler masallardaki olağanüstülüğü destekler ve geliştirir.

\section{Masallar ve Toplumsal Cinsiyet}

Sosyal bir varlık olan insan, toplum içinde var olmaktadır. Bu sebeple toplum tarafından kabul edilmek, takdir görmek bireyler için önemli bir ihtiyaçtır. Toplumun cinsiyet gruplarına yükledikleri görev ve sorumluluklar; kişilerin gündelik yaşamdaki faaliyetlerini, olaylara bakış açılarını, bir durum karşısındaki duruşlarını etkiler ve şekillendirir. Nirun (1991: 3)'a göre kişiler, içinde yaşadıkları toplumun çıktılarına göre yaşama şekillerini belirlemeye çalışırlar.

Toplumsal cinsiyet (gender), kadın veya erkek olma durumunun toplum ya da kültür tarafından kişiye yüklenen anlam ve beklentileri ifade eden, içinde psiko-sosyal özellikler bulunduran bir kavram olarak tanımlanmaktadır (Dökmen, 2009: 20).

Masalların toplum ile olan yakın ilişkisi özellikle sözlü kültür ürünlerinden olmasından kaynaklanmaktadır. Anlatılar, kulaktan kulağa kuşaklar arasında aktarılırken her bir anlatıcıda yeni şekiller alır, varyantlaşır. Bu sebep ile canlı, değişen ve gelişen bir özellik arz eder. Toplumun kültür dinamiklerinin aktarıcısı olması, kahraman kadrosunda yer alan bireylerin -her ne kadar olağan dışı olaylar ile karşılaşılsa da- gerçek hayat insan profilleri ile olan ilgileri, masalların toplumsal cinsiyet bağlamında araştırılması gerekliliğini doğurmaktadır.

Masallarımız daha çok, kadın anlatıcıların aktif rol oynadığı aktarım süreçleri ile yayılım sahası gösterir. Bu sebepten dolayı, anlatıların büyük bölümünde birbirinden çok farklı kadın profilleri, metinlerde kahraman olarak karşımıza çıkar. Toplum hayatında geriye itilmiş kadınların 
içinde bulundukları çeşitli zor durumlardan kurtulma yolunda verdikleri mücadeleleri, genç kızlık hayalleri en sık işlenen konular arasında yer alır. Boratav'ın konuyla ilgili tespiti şu yöndedir: "Masalın hangi çeşidinde olursa olsun zorluklardan yılmayan, sabır ve akıllarıyla mutlu sona ulaşan genç kız ve kadın tipleri kalın çizgilerle öne çıkmaktadır" (2000: 84).

Akar (2006), "Türk Masallarında Kadın Figürü Üzerine Bir İnceleme” isimli çalışmasında şu yorumda bulunur:

Kabul eden anneler, reddeden ve ürküten üvey anneler, iffetini ve onurunu korumaya çalışan kadınlar, meşakkâtli durumların üstesinden gelmeye çalışan anne, baba ve çocuklar gibi çevremize baktığımızda aslında masalların gerçek hayatta her an yenilendiğini görürüz ( Akar, 2006: 274). Aktarılanlardan anlaşılacağı üzere toplumun cinsiyet gruplarına verdiği görevlerin yansımaları, masallarımızda açıkça görülmektedir.

\section{Masallar ve İletiler}

Masallar ait oldukları toplumların gelenek, görenek ve inançlarını yansıtırken aynı zamanda bu toplumların sosyal, kültürel, ekonomik verilerini de okuyucularına sunarlar. "Doğudan derlenen masallarda su içerken yılan yavrusu yutma, ağabeyi ölen erkek kardeşin yengesi ile evlenmesi, kızların bekâretlerini koruma mücadeleleri, kız çocuklarının babalarına karşı gelmemeleri, bu uğurda istemedikleri pek çok şeye razı olmaları, sessiz ve çilekeş kadınların her zaman makul sayılması gibi olayların konu edindiği metinlere sıkça rastlanır. Anlatılanlar toplumumuzun gelenek ve göreneklerini, sosyal ve kültürel yapısını yansıtmaktadır. Bu işlevler iletiler aracılığı ile aktarılmaktadır" (Helimoğlu Yavuz, 2002: 30).

Masallar, iletileri aracılığıyla insanları iyiliğe, güzelliğe, erdemli davranmaya yöneltirler. Öyle ki anlatılarda kötüler cezalandırılırken iyiler ödüllendirilmektedir. Değerler eğitimi açısından masal türünün kullanılması bu sebeptendir. Mutlu son her zaman erdemli davranışlar gösteren kahramanların hakkı olarak görülmektedir. Dinleme ortamlarında alımlayıcının çocuk olduğu kişilik gelişimi devam eden dinleyiciler için masallar aracılığ 1 ile verilen iletiler, toplum nezdinde kabul gören ve görmeyen davranış özelliklerini aktarmakta, böylece çocuğu gerçek hayat ortamlarına hazırlamaktadır.

“Toplumsal bütünlüğün önemli bir parçası olan ileti kavramı, günümüz teknolojisinin gösterdiği gelişimler doğrultusunda toplumdaki yerini korumaya devam etmektedir. Bireyin bakış açısı, duygu ve düşünceleri sahip olduğu, bilinçaltına işlenen iletiler üzerinden şekillenir. Günümüzde kişilerin maruz kaldığı uyaran sayısı düşünüldüğünde "ileti” kavramının önemi aynı ölçüde artmaktadır" (Karakuş ve Deniz, 2019: 1670).

İletileri okuyucuya ulaştırmada kahramanlar çeşitli roller üstlenirler. Anlatıcılarının daha çok kadınlar olması sebebiyle masallardaki kadın kahraman kadrosu oldukça geniş yer tutmaktadır. Kadın rollerini, Helimoğlu Yavuz (2002: 62) şu başlıklar altında toplamıştır:

- Mutluluğu yakalamak için uğraş veren olayların gidişini yönlendiren akıllı, vefalı, özverili, direnişken kadınlar

- Kıskanç ve iftiracı kadınlar

- Kötü kalpli üvey anneler, büyücü kadınlar ve acımasız dev anaları

- Cinsel tacizlere uğrayan kadınlar

- Eşlerine ihanet eden kadınlar

- Yalan ve kurnazlıkla mutluluğa ulaşmak isteyen kadınlar

- Akılsız, beceriksiz, sağduyusuz kadınlar

Yapılan gruplandırmaya bakılarak masal kahraman kadrosuna dâhil olan kadınların gerçek hayattaki kadın profilleri ile benzerlik gösterdiği yorumu yapılabilmektedir. Olumlu ve olumsuz kadın profilleri, toplum tarafindan benimsenen, kabul edilen duygu ve 
davranışlar ile toplum nezdinde hoş karşılanmayan duygu ve davranışları masal alımlayıcısına aktarmaktadır.

\section{Çalışmanın Amacı ve Önemi}

Günümüz toplumu, kadına tek bir açıdan bakmaktadır. Bir kadın ya güzelliğiyle ya da zekâsı ile öne çıkmakta, çok az kadının bu iki özelliği bir arada taşıdığı kabul edilmektedir. Oysa masallarımızdaki kadınlar hem güzellikleri hem güçleri hem de sahip oldukları erdemler bakımında pek çok olumlu özelliği tek bir kişilikte taşıyabilmektedir. Pek çoğu aile birlikteliğini korumak için ellerinden gelen her şeyi yapmaktadır. Hanedeki huzurun sağlanmasında kadının çabası, masallarımızda açıkça görülmektedir. Olumsuz kişilik özellikleri gösteren kadınlar, kadın düşünce dünyasının sınırsızlığını ortaya koymaktadır. Tüm bunlar masallardan kadın dünyasına pencere açma gerekliliği doğurmakta, çalışma bu noktada önem kazanmaktadır.

Yapılan okumalarda masallarımızdaki kadın karakterler üzerine yapılmış çalışmaların yetersizliği dikkat çekmiştir. Alandaki bu eksiklik, çalışmanın çıkış konusu olmuştur. Çalışmanın amacı: genelde, toplumsal cinsiyet bağlamında kadına dair bakış açısı oluşturabilmek, özelde kadınların masal iletilerini vermedeki rolünü açığa çıkarmaktır.

\section{Yöntem}

\section{Model}

Çalışmada örneklem grubunda yer alan masallar: Naki Tezel, Tahir Alangu, Pertev Naili Boratav ve Aydın Parmaksız'ın eserlerinde yer alan masallardır. Masallar çözümlenirken nitel araştırma yöntemlerinden doküman analizi yöntemi kullanılmıştır. Çalışmaya konu olacak masallar seçilirken kahraman kadrosu dikkate alınmış ve özellikle kadın kimliğinin öne çıktığı masallar seçilmiştir.

Nitel araştırmada, verileri doğrudan toparlayabileceğimiz gözlem ve görüşme imkânının olmadığı durumlarda, araştırma konusu ile ilgili basılı materyaller de araştırmaya dâhil edilebilir. (Yıldırım ve Şimşek, 2018: 189).

Doküman incelemesi tek başına bir araştırma yöntemi olabildiği gibi ek bilgi kaynağı olarak da kullanılabilir. Doküman incelemesi, araştırılması hedeflenen olgular hakkında bilgi içeren yazılı materyallerin analizini kapsar. Tarihçilerin, dilbilimcilerin ve antropologların sıklıkla tercih ettiği bir yöntemdir (Yıldırım ve Şimşek, 2018: 189).

\section{Verilerin Toplanması ve Analizi}

$\mathrm{Bu}$ çalışmada kadın kahramanların etrafında oluşan masallar seçilmiş ve bu masalların iletilerini verme sürecinde kadın kimliğinin nasıl kullanıldığı incelenmiştir. Bir Göze Bir Gül, Ardıç Ağacı, Deli Kadın, Cazı Kız, Benli Bahri, Erler Karısına Koca Olmaya Giden Keloğlan ve Dev Anast ile Keloğlan masalları incelemeye konu edilmiştir.

Araştırmacılar tarafından Naki Tezel, Tahir Alangu, Pertev Naili Boratav ve Aydın Parmaksız'ın eserlerindeki masallar iki farklı süreç ile okunmuştur. İlk okuma amaçsız olarak, ikinci okuma ise masallardaki kadın kahramanların iletileri vermedeki rolü merkezinde yapılmıştır. Elde edilen veriler, formlara işlenmiştir. İşlenen veriler, araştırmacılar tarafından ortaklaştırılarak bulgular kısmında incelenmiştir.

Toplanan veriler içerik analizi ile derinlemesine incelenmiş, iletileri vermede kadın kahramanların rolü araştırılmıştır. "İçerik analizi, metin veya metinlerden oluşan bir kümenin içindeki belli kelimelerin veya kavramların varlığını belirlemeye yönelik yapılır. Araştırmacılar bu kelime ve kavramların varlığını, anlamlarını ve ilişkilerini belirler ve analiz ederek metinlerdeki mesaja ilişkin çıkarımlarda bulunurlar” (Büyüköztürk vd. 2013: 240).

\section{Bulgular}

Turkish Studies, 16(1) 
Deli Kadın masalında (Parmaksız, 2017: 73), eksik akıllı bir kadının, kocasını memnun etme çabasına şahit olunmaktadır. Kadın, kocasının her istediğini yapmakta fakat bunları yerine getirmekte pek de akla uygun olmayan yollar tercih etmektedir. Öyle ki eşinin istediği gömleği dokutmak için kurbağalardan yardım istemektedir. Bıraktığı yünleri bulamayan kadın, bir küp dolusu altınla eve gelince, kocası duruma çok sevinse de altınlar kısa sürede elden çıkacaktır. Kadın, tabak ve çanakla bir küp dolusu altını takas edince duruma çok sinirlenen kocası, kadını dövüp evden kovmuştur. Geceyi sokakta geçiren kadın sabaha karşı başında havlayan köpekleri, miyavlayan kedileri ve ağlayan deveyi pişman olan kocası gönderdi zannedip altın yüklü deveyi de alıp eve dönmüştür. Adam altınların hatırına karısını eve alsa da çok geçmeden anlaşılır ki deve, padişahın kaybolan devesidir ve aranmaktadır. Kadıya ifade veren kocasını büyük bir cezadan kurtaran kadın, o günden sonra eşiyle mutlu bir yaşam sürmekle ödüllendirilmektedir.

$\mathrm{Bu}$ metinde tek kadın kahraman vardır. Bu kahraman, üzerinde birkaç kadın profilini taşır. Eşini mutlu etmek için her yolu deneyen, uğradığı hakaretlere rağmen evini bırakmayan, özverili, vefalı bir kadın kahramandır. Aynı zamanda problem çözme becerisi gelişmemiş, beceriksiz bir kadın profilindedir. Eşinin kendine verdiği görevleri akı1 dışı yollar ile çözmeye çalışmaktadır. Bulduğu çözüm önerileri, evlilik yapmış erginlenmesini tamamlamış bir kadın zekâsının ürünleri değildir. Masal, kahraman üzerinden evlilik hayatındaki birlikteliğin büyük ölçüde kadınların alttan almalarına, özveride bulunmalarına bağlı olduğu iletisini taşımaktadır.

Ardıç A ̆gacı (Parmaksız, 2017: 84), isimli masalda üvey anne profili ile karşılaşırız. Masallarımızda üvey anneler kötü kalpli acımasız kadınlar olarak karşımıza çıkmaktadır. Bunun sebebi belki de toplumumuzun, ilk eşine sadık kalmayan erkekleri cezalandırmak istemesidir. Öyle ki yapılan yeni evlilikte üveylik sadece annelik ile sınırlandırılmaz. Bu kadınlar hanedeki huzuru kaçıran, paragöz, geçimsiz, memnuniyetsiz bir portre çizmektedirler. Masaldaki üvey anne, acımasızlıkta çok üst seviyelerdedir. Çekemediği çocuğu öldürmekte, etini ise babasına yedirmektedir. $\mathrm{Bu}$ yaptıklarını da -bir şekilde- masalın sonunda cezalandırılana kadar saklayabilmektedir.

Çoğu zaman güzel kıza duyulan kıskançlık duygusunun kırbaçladığı tehdit edici unsurlar, Ardıç A ̆gacı masalında erkek çocuğa yöneltilmiştir. Bu masalda üvey annelik motifine yardımcı olan üvey kardeşlere rastlanmamaktadır. Özellikle güzel kızın kıskanıldığı masallarda üvey anneler, işkenceyi öz kızları ile planlamakta ve yönetmektedir. İncelenen masalda ise üvey kardeş bir kızdır ve kıskançlık duygusu hâkim değildir. Nitekim annesi tarafından öldürülen üvey kardeşinin durumu ile ilgili endişeye kapılmaktadır. Masal, eve dışarıdan gelen kadına karşı dikkatli olunmalıdır, aksi halde hanenin huzuru bozulacaktır iletisini taşımaktadır.

Bir Göze Bir Gül (Tezel, 2019: 145), isimli masalda da kahraman yine bir üvey annedir. Kadın kahramanlar açısından oldukça zengin olan bu masalda evin küçük kızı güzelliği sebebiyle şehzadeye gelin gidecektir. Bu durumu kıskanan üvey anne, evliliğin gerçekleşmemesi için türlü oyunlar düzenlemekte ve genç kızı çok zor durumlara sürüklemektedir. Ancak genç kız başına gelenlere sabır ile direnir ve üvey annesinin elinden aldığı mutluluğu yakalamak için aklının gücüyle mücadele verir. Masalın sonunda da hak ettiği mutluluğa ulaşır. Üvey anne ise cezalandırılır. Masal, mutluluğa giden yol uzun ve çetindir, iletisini taşımaktadır.

Masalda iki ayrı kadın kahraman üzerinden birbirine zıt, iki farklı kadın profili çizilmiştir. Üvey anne; toplumumuz tarafından reddedilen acımasız, kıskanç bir imaj çizerken; genç kız, toplum nezdinde benimsenen sabırlı, iyi niyetli, akıllı bir kadın profilindedir.

"Masallarda özel mekânda 'ötekileştirilen' kadınlar genellikle üvey çocuklar, aileye sonradan katılan kardeşler ya da gelinlerdir" (Ölçer, 2003: 38). İncelenen masalda evin güzel kızı üvey anne tarafindan yol üzerine bırakılmıştır. Masallardaki üvey evlatlar, kurulan çeşitli tuzaklar ile evden gönderilmektedir. 
Dev Anası ile Keloğlan (Alangu, 2016: 30), masalında zalim bir kadın kahraman üzerinden olaylar kurgulanmaktadır. Dev Anası, annelerini kaybeden küçük çocukları bir şekilde evinde misafir edip gece hepsini yemeği planlamaktadır. Ancak Keloğlan, sivri zekâsı sayesinde bu planın farkına varır ve kendisini de kardeşlerini de Dev Anası'nın gazabından kurtarır. Buradaki kadın kahraman, insan eti yiyen bir canavar olarak tasvir edilir. Masal, akılsızca atılan adımlar kişiyi zora sürükler, iletisini taşımaktadır. Benzer bir kadın kahramana Erler Karısı'na Koca Olmaya Giden Keloğlan (Boratav, 2017: 51), masalında rastlarız. Erler Karısı memelerini omuzuna atmış güneşlenirken Keloğlan gelir ve kadının memelerinden süt içer. Olaylar zinciri iki kahramanın bu şekilde karşılaşması ile başlar. Diğer masalda olduğu gibi burada da kadın kahraman canavar görüntüsündedir. Her iki masalda da kadınlar zaaflarının kurbanı olmuştur. Aklıyla hareket eden Keloğlan ise kadınların zalimce planlarından kurtulabilmiştir. Masal, yakınlık gösteren her kişiye güvenilmemelidir, iletisini taşımaktadır.

Toplumumuzda özellikle cahil kalan kesimin inanışına göre kadınlar şeytani canlılardır ve her türlü kötülüğü yapabilecek sinsiliktedir. Bu gibi masalların bahsedilen düşüncenin ürünü olmaları kuvvetle muhtemeldir.

Erkek, görevi kötülük yapmak olan kadın tiplerini savaşarak ya da kurnazlığını kullanarak alt eder. Dev anası, memesi emildiğinde teslim olur. Teslimiyet bekâretin söz konusu olduğu durumlarda ilk öpücük karşısında da gösterilmektedir. Dev anasının memesini emen erkek kahraman artık onun oğlu olmuştur. Ancak masal sonunda hiçbir gerekçesi kalmayan kahraman teslimiyet göstermiş olsa da kötücül dişiyi öldürmeyi tercih edecektir (Sezer, 2019: 47).

Dev anaları, masallarımızda insan eti ile beslenmektedir. Kahramanı bir şekilde etkisiz hale getirip akşam yemeği olarak yemeyi planlamaktadırlar. Bir yamyam olan dev analarından kurtulmanın yolu memesini emmekten geçmektedir. Ancak annelik güdüsü kullanılarak tehlikesiz hale getirilmektedirler. Zarar verici yanları bertaraf edildiğine göre dev anaları öz anne rolüne geçmektedir. Ancak her kötü karakter gibi masal dünyası onlar için de kötü bir son hazırlamaktadır.

Benli Bahri (Boratav, 2017: 75), masalında fakir bir kız ana kahramandır. Kedi kılığındaki genç şehzade, her gece fakir kızı ziyaret etmekte ve giderken değerli bir taş bırakmaktadır. Kız, pahada epey ağır olan bu taşlar sayesinde zengin olunca, kedideki kerameti anlamak üzere bir gece peşine takılır. Kedinin gerçekte yakışıklı bir şehzade olduğunu görür. Ziyareti sırasında aslında evli olan kedi kılığındaki şehzadenin, karısı tarafından aldatıldığına da şahit olur. Bir gece gördüğg̈ her şeyi anlatır. Karısının kendisini lalasıyla aldattığını öğrenen Benli Bahri çok sinirlenir, intikam almak için yedi senelik bir yolculuğa çıkar. Bu yolculuk sonunda intikamını alır ve geri dönüp kendisini bekleyen kız ile evlenir.

Bu masalda kocasını aldatan bir kadın kahramandan bahsedilir. Masal, insan etrafındakilere karşı dikkatli olmalıdır çünkü bazen en büyük kötülükler, en yakınlarımızdan gelmektedir, iletisini taşımaktadır. Toplum değerlerimize aykırı olan bu davranış, kadının kocası tarafından cezalandırılır. Eşine ihanet eden kadın, kendisine sevgili olarak kocasının lalasını seçmiştir. Seçilen kişinin aileye yakın olması masal dinleyicisine örtük bir mesaj sunmakta, ihaneti uzaklarda aramamasını öğütlemektedir. Masalın iletisi iffetsiz ve namuslu kadınlar üzerinden verilir. Kadınların ne kadar sadık olabileceği anlatılırken aynı zamanda bir zamanlar güvenilir olarak görülen kadınların nefsine yenik düşebilecek olabilmeleri de dinleyicilere hissettirilir. Mutluluğa giden yol uzun ve çetindir, iletisi fakir kız üzerinden; insan bazen en büyük kötülüğü en yakınlarından görür, iletisi ise şehzadenin karısı üzerinden verilmektedir.

Cazı Kız (Boratav, 2017: 103), masalındaki erkek kahraman iki kadınla evlidir. Bir gün tehlikeli bir iş için evden ayrılır. Gitmeden karılarına: "Tuz su olursa su da kan olursa al atımı koyuverin. O beni bulur." der. Kuma kadınlar günlerce tuzdaki ve sudaki değişimleri gözlerler ve uygun zaman gelince eşlerinin başının derde girdiğini anlayıp atı koyuverirler. At gider sahibini bulur ve kahramanın hayatını kurtarır. 
Bu masalda kumalık ilişkilerinden bahsedilmektedir. Toplumumuzda görülme oranı azalsa da bu durumun yaşandığı aileler hâlâ varlığını sürdürmektedir. Her ne kadar istenmeyen bir durum dâhi olsa bir kez başa geldiyse yapılacak bir şeyin olmadığı, bundan sonrasında eşlere düşenin aile bütünlüğünü korumak olduğu, masalın iletisidir. Nitekim kuma olan kadınlar, eşlerine karşı kırgın ya da kızgın değildirler. Onun başına bir şey gelmesin diye günlerce tuz ve sudaki değişimi gözler ve uygun zamanda kurtarıcılık görevi üstlenen atı yardımcı olarak gönderirler. Masalda kumalık ilişkilerinde karşı1lıklı anlayış olursa aile bütünlüğü bozulmadan birlikteliğe devam edilebilir, iletisi vardir.

\section{Sonuç, Tartışma ve Öneriler}

Halk edebiyatı araştırmalarında masal ilgi çeken bir tür olmuş ve birçok çalışmaya konu edilmiştir. Sözlü kültür ürünü olmasına rağmen zamanın bir noktasında yazı altına alınmaları masalların sözlü kültürle olan bağını koparmış varyantlaşmaların önünü kesmiştir. Masal girebildiği türlü ortamlar sayesinde kültürel pek çok unsuru içine almış, gezdiği coğrafyalara kültürel hafizayı taşımıştır. Bu sebep ile amaçlı yapılan masal okumaları toplumsal bakış açılarının farkına varılmasına, kültürel kodların çözülmesine yardım edecektir.

Deli Kadın masalında gerçeklik algısı bozulmuş bir kadın kahraman ile karşılaşılmıştır. Masal, yaşanılan sorunlar karşısında mantıklı çözüm önerileri üretilmelidir ve aile bütünlügünü sağlamak kadının görevidir iletilerini taşımaktadır. Kadın, kendisine verilen sorumlulukları yerine getiremediği için kocası tarafından evden uzaklaştırılsa da uğradığı hakaretlere rağmen bir şekilde evine dönmenin yolunu bulmuştur. Masal bu yönüyle halk dilindeki, "Yuvayı dişi kuş yapar" sözünü hatırlatmaktadır.

Masallarda yuvayı yapan ve sürekliliğini sağlamak için uğraşlar veren, bazen ikinci bir kadına bile katlanan ailesini her şeyin üzerinde tutup koruyan, kollayan kadın kahramanlardır. "Kadın ölüm anında dahi kendisinden sonraki hane sürekliliğinin sağlanabilirliği üzerinde düşünür" (Ölçer, 2003: 36). Nitekim "Deli Kadın" masalında da kadın kahraman, kocasını uyguladığı şiddette rağmen affetmiş, sözünden çıkmamıştır.

"Ardıç Ağacı” masalında kadın kahraman üvey anne rolündedir. Masallarımızda üvey anneler eşlerinin ilk evlilikten olma çocuklarına sistemli bir işkence metodu uygulamaktadır. Kadın için itibar kazanma yollarından biri de anne olmaktır. İktidar gücünü ele alabilmesi için çocuğa ihtiyaç duyar. Ancak çocuk öz olmalıdır. Bu sebep ile kendi doğurmadığını, itibarını temsil etmediği için sevmez. Üvey anne dişarıdan gelmiştir ve ev içinde yerini sağlama alma ihtiyacı duyacaktır. Bu ihtiyacını gidermek için üvey olandan kurtulmalıdır (Sezer, 2004: 70).

Üvey anneler tarafından çocuklara yapılan işkenceler, bugün de hâlâ dizi ve filmlerimizin ilgi çekici konularındandır. İnsani tüm değerlerden yalıtılmış şekilde sahneye çıkan bu kadın tipleri kıskançlıklarının ya da hırslarının kontrolünde hareket etmektedirler.

"Hane içine sonradan giren kadınlar, her zaman kaderlerine razı olup ömürlerinin sonuna kadar "öteki" konumunda kalmazlar. Onlar da bir süre sonra hane içinde 'esas kadın' konumuna geçmek için çaba harcarlar” (Ölçer, 2003: 41). Üvey anneler için varoluş mücadelesi masallarımızda sıkça işlenen konular arasında yerini almaktadır.

Masalda cezalandırılan sadece üvey anne değildir. Baba da bir yamyam gibi insan eti yemektedir. Üstelik etini yediği canlı kendi oğludur. Akşam eve döndüğünde oğlunu görememekte ancak karısının söylediği basit bir yalana inanıp çocuğunu merak etmemektedir. "Masallarda ikinci evliliği yapan kadının kötülüğü, yani üvey anne yalnızca ilksel olanın doğruluğunu kanıtlamak için fazlasıyla veri sunar. Üvey anne kötü, baba da bu kadını seçtiği için hatalıdır” (Sezer, 2004: 99).

Masallarımızdaki üvey annelerin ikna güçleri oldukça yüksektir. Yaptıkları türlü işkenceleri, söyledikleri yalanları, kurdukları hain planları ustalıkla gizlemekte, ana kahramanları mağdur edene kadar istediklerini yaptırmak konusunda karşısındaki erkeği ikna etmektedirler.. 
"Bir Göze Bir Gül” masalında da acımasız bir üvey anne ile karşılaşılmaktadır. Bu masalın "Ardıç Ağacı" isimli masaldan farkı üvey anneler için tehdit unsuru olarak görülen çocukların cinsiyetlerinin farklı olmasıdır. "Ardıç Ağacı" isimli masalda kıskanılan, erkek çocuktur. Kıskanılmanın yönü maddi konular ile ilgilidir. "Bir Göze Bir Gül” masalında ise kıskanılan, güzelliği sebebiyle evin kızıdır. Üvey anne rolüne yardımcı olarak üvey kız kardeş rolü de masalda kullanılmıştır. "Ardıç Ağacı" isimli masalda üvey kardeşlerin cinsiyetleri birbirinden farklıdır. Bu sebep ile kardeşler arasında kıskançlık ilişkisi görülmemektedir. Nitekim kız kardeş ağabeyine zarar verdiği düşüncesi ile gözlerinden yaş yerine kan akıtmaktadır. "Bir Göze Bir Güll” masalında ise üvey kardeşler evlilik yaşı gelmiş iki kızdır. Kıskançlık, farklı olan fiziksel özellikler sebebiyle masala konu olmuştur.

Masal kahramanı güzel genç kız annesi tarafindan güvey evine giderken yol üzerinde muhtaç bir halde bırakılmıştır. Bakire kız için ev dışına çıkış tehlike arz etmektedir. "Bakire bir kızın, hangi nedenle olursa olsun ev içinden ayrılması iffetine zarar gelmesi anlamındadır" (Ölçer, 2003: 25).

Erkeğin aksine tek başına evinden ayrılan kızlar ya kovulmuştur, ya kaçırılmıştır ya da kaybolmuştur... Aksi durumlarda ne ölçüde şiddet görürse görsün hizmetçilik yapmak, dayak yemek pahasına da olsa evinden ayrılmaya çalışmaz (Sezer, 2004: 22). Genç kızın üvey annesiyle çatışarak ailesinden ayrılışıyla büyüme süreci başlar. Erginlenme süreci masalın sonunda evlilik ile tamamlanır.

"Dev Anası ve Keloğlan” masalı ile "Erler Karısına Koca Olmaya Giden Keloğlan" masallarında kadın kahramanlar ürkütücü görüntüleriyle bir tehdit unsuru olarak görülmektedir. Toplum nezdinde kadından beklenen, erkeğe bağlı olmasıdır. Erkeğin gücü, kadın üzerindeki hâkimiyeti ile ölçülmektedir. Masallarımız incelendiğinde, mutlu sonu hak eden genç kızlarımızın edilgen bir tavır sergilediği görülmektedir. Öyle ki uğradığı işkencelere ses çıkarmazlar, bir dağ başında kendisini kurtarmaya gelecek şehzadeleri beklerler. Kurtulmak ya da kötü kaderlerini değiştirmek için hiçbir girişimde bulunmazlar. $\mathrm{Bu}$ yönleriyle edilgendirler. Masalın sonunda kahramanlık gösteren şehzade ile evlenir ve mutlu bir hayat yaşarlar.

Masallarımızda tehlike arz eden kadınlar, kendi kaderlerini yönlendirmeye çalışan hayatlarında aktif rol alabilen kadınlardır. Bir erkeğin iradesi ile hareket etmezler. Bağımsız kadın tipleri masallarımızda çoğu zaman olağanüstü özellikler gösteren cadılar, dev anaları, cinler gibi varlıklar aracılığıyla verilmektedir. Keloğlan, incelenen iki masalda da dev anasını etkisiz hale getirmeye çalışmaktadır. Bağımsız kadınlar olan dev anaları erkek kahraman tarafından alt edilmiştir.

"Benli Bahri” masalının konusu "Binbir Gece Masalları"nda işlenen kadının sadakatsizliği konusu ile ortaktır. Binbir Gece Masalları'nda Şahzaman ve Şehriyar, karıları tarafından aldatılan erkeklerdir. Şehriyar intikam yemini etmiş, her gece bir bakire ile evlenip sabahında idam ettirmiştir. Ta ki vezirin kızı Şehriyar ile tanışana kadar. Günümüz toplumunda da kadının ihaneti erkeğinkinden daha aşağılayıcıdır. "Erkektir yapar" ifadesi ile halk diline yansıyan durumların karşılığı kadınlar için iffetsizlik ile bağdaştırılır. Nitekim "Cazı Kızı" masalında kumalık ilişkisine şahit olunmaktadır. Erkek için ikinci olmak aşağılık ve asla kabul edilemez bir durumken masalda kadınlar kuma olmayı dert etmemektedir. Öyle ki kendilerini bu duruma düşüren kocalarının başına bir iş gelmemesi için günlerce suyun başında beklemişlerdir. Toplum tarafından bakıldığında da sadakatsizlik erkek ve kadın için aynı anlama gelmemektedir. Kadın bu davranışı sonucunda aşağılanıp reddedilirken erkek için "ikinci bir şans" mutlaka tanınmaktadır. Erkek iktidar güç olarak öne çıkarken bu gücü başka bir erkek ile paylaşmayı reddeder. Bu durum masallarımızın toplumsal cinsiyet rollerini gerçek hayat dinamiklerine uygun olarak işlediğinin kanıtıdır.

Toplumsal cinsiyet kavramı, cinsel kimlikten ayrı olarak toplumun cinsiyetlere yükledikleri görevleri ifade etmektedir. Toplum tarafından kadına biçilen değer ve verilen sorumluluklar 
masallarımıza sıkça konu olmuştur. Bunun en önemli sebeplerinden biri anlatıcılarının kadın ağırlıklı olmasıdır. Kadınlar anlatılarda farklı roller ile kurguya dâhil edilmektedir. Kimi zaman aşkının peşinde koşan, kimi zaman zekâlarıyla içine düştükleri zor durumdan kurtulan, kimi zaman aileyi koruma görevi üstlenen kadınların en çok önem verdiği husus bu görevleri yerine getirirken namuslarını korumaktır. Bu uğurda canlarından bile hiç düşünmeden vazgeçebilme cesaretini gösterirler. Ancak bilindiği üzere masallarda zıtlıklardan çokça faydalanılmaktadır. Erdemli, iffetli, yiğit kadınlar kıskanç, iffetsiz, hilekâr kadınlar ile aynı kurguda yer almaktadır. İyilerin masumluklarını kanıtlamak için kötülere ihtiyaçları vardır. Masal dünyası tüm bu zıtlıkları olağanüstülükler ile birleştirerek okuyucuya/ dinleyiciye sunmaktadır.

Kadın profillerinin iletiyi vermedeki rollerinin incelendiği bu çalışmada belirlenen masallar üzerinden ulaşılan bulgular sıralanmıştır. Yapılan çözümlemeler sonucunda, sözlü kültür ürünlerinin de tıpkı yazılı kültürde üretilmiş kurmaca edebî metinler gibi incelendiğinde edebiyat toplum ilişkisini, kolaylıkla ortaya çıkartılabileceği saptanmıştır.

Günümüz medyasını çokça meşgul eden kadın-erkek ilişkilerine çalışmamızda masallar dünyasından pencere açılmıştır. Modern dünyanın ve geleneksel anlayışın kadın-erkek rolleri arasında bocalayan bireyleri için bu gibi çalışmaların kültürel hafızada toplumsal cinsiyet rollerinin anlaşılması açısından önemi büyüktür. Elde edilen sonuçlardan ve alan yazını okumalarından hareketlerle şu önerilerde bulunabilir:

Masalların toplumsal hayatla ilgili bağlarının araştırıldığı çalışmalara daha fazla önem verilmeli, masallarımızdaki kadın-erkek profillerinin ve bu profillerin birbiri ile ilişkilerini inceleyen çalışmaların sayısı arttırılmalı, çalışma sonuçları sosyoloji ve psikoloji gibi bilim dallarıyla ilişkilendirilmeli bu sayede geleneksel anlayış ve modern dünya algısı arasında bocalayan bireylere farklı bakış açıları sunulmalıdır.

\section{Kaynakça}

Akar, Ö. (2006). Türk Masallarında Kadın Figürü Üzerine Bir İnceleme, [Yüksek Lisans Tezi], Gazi Üniversitesi Sosyal Bilimler Enstitüsü.

Alangu, T.(2006). Keloğlan Masalları. YKY.

Arsoy N.(2011), Türk Masallarında Ataerkillik, Toplumsal Cinsiyet Ayrımcılığı ve Kadın, [Yüksek Lisans Tezi], Kafkas Üniversitesi Sosyal Bilimler Enstitüsü.

Artun, E. (2012). Anonim Türk Halk Edebiyatı Nesri. Karahan Kitabevi.

Boratav, P. Naili (2000). 100 Soruda Türk Halk Edebiyatı. Gerçek Yayınevi.

Boratav, P. Naili (2017). Az Gittik Uz Gittik. İmge Kitabevi Yayınları.

Büyüköztürk vd. (2013). Bilimsel Araştırma Yöntemleri. Pegem Akademi.

Dökmen, Zehra Y (2009). Toplumsal Cinsiyet- Sosyal Psikolojik Açılamalar. Remzi Kitabevi.

Helimoğlu Yavuz, M.(2002). Masallar ve Eğitimsel İşlevleri. T.C Kültür Bakanlığı.

Karakuş, N. \& Deniz, B. (2019). Türk ve Alman Masallarında Yer Alan İletilerin Küresel Gelişime Katk1 Sağlayıcılık Yönünden Karş1laştırılması, Uluslararası Türkçe Edebiyat Kültür Ĕ̈itim Dergisi, 8(3), 1666-1686.

Nirun, N. (1991). Sistematik Sosyoloji Yönünden Sosyal Dinamik Bünye Analizi, Atatürk Kültür Merkezi Yayını.

Ölçer, E.(2003). Türkiye Masallarında Toplumsal Cinsiyet ve Mekân İlişkisi, [Yüksek Lisans Tezi], Bilkent Üniversitesi Ekonomi ve Sosyal Bilimler Enstitüsü. 
Parmaksı A.(2017). Freud Bana Masal Anlatsa. Bilge Kültür Sanat Yayınları.

Sezer, Ö. (2004). Masallarda Toplumsal Cinsiyetin İşlenişi, [Yüksek Lisans Tezi], Ankara Üniversitesi Sosyal Bilimler Enstitüsü.

Sezer, Ö. (2019). Masallar ve Toplumsal Cinsiyet. Kor Kitap.

Şen, G. (2019). Türk Masallarına Psikanalitik Yaklaşım, [Yüksek Lisans Tezi], Muğla Sitkı Kocaman Üniversitesi Sosyal Bilimler Enstitüsü.

Tezel, N. (2019). Türk Masalları. Alfa Basım Yayın.

Türkçe Sözlük (1998). C.2. TDK Yayınları.

Yıldırım, A. \& Şimşek, H. (2018). Sosyal Bilimlerde Nitel Araştırma Yöntemleri. Seçkin Akademik ve Mesleki Yayınlar. 